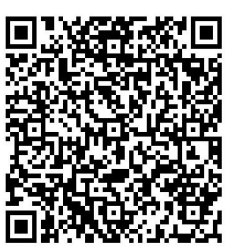

\title{
HOSPITALITY EDUCATION AND ADVISORY COMMITTEES IN INDIAN UNIVERSITIES: AN ANALYSIS OF ACADEMIC SUCCESS
}

\author{
Mohinder Chand* \& Ashish Dahiya**
}

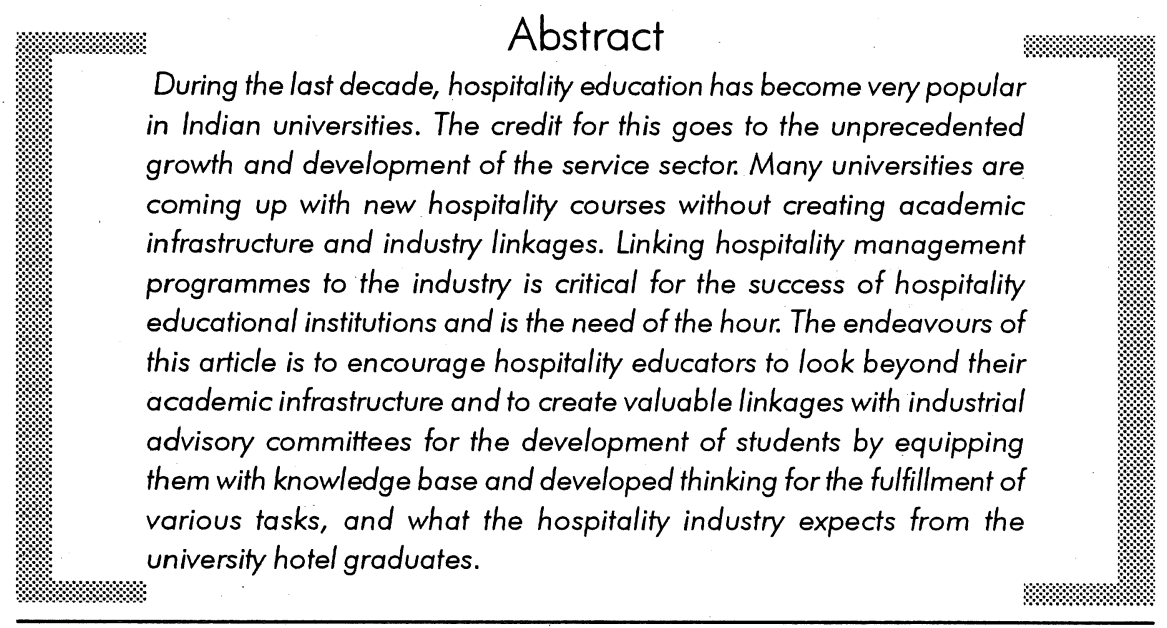

* Associate Professor in Department of Tourism \& Hotel Management Kurukshetra University Kurukshetra, Haryana.

** Reader - Hotel Management, Centre for Mountain Tourism \& Hospitality Studies HNB Garhwal University Srinagar Garhwal Uttarakhand. 


\section{Introduction}

There has been a tremendous growth in the Indian hospitality Industry in the last few years and as per the prediction of WTTC (World Travel \& Tourism Council) the country is poised to become the second fastest growing tourism economy in the world by 2014 . In last few years, the country has seen a significant increase in the number of visitors. India has emerged as a favored destination for the hospitality investors. Various hotel groups, both national and international, are investing in the Indian Hotel Industry. With the boom in economy and elevated life standards, India is the market for multinational companies. Now, high-end tourists are patronizing India as well. Hotels are amongst the most visible and important aspects of a country's infrastructure and the hotel industry is closely linked to the tourism industry. A number of factors like the promotion of tourism and rapid industrial progress have given a boost to hoteliering. The recent liberalization of trade and opening up of the economy will further lead to a revolutionary growth in this sector. Further, the report published by the World Bank (2007) cites that the demand of skilled courses like Multimedia, Hospitality \& Hotel Management, Tourism, and Telecommunication \& Aviation is emerging at a very high rate in India.

With increasing competition in the hospitality industry globally and the growing demands of efficient services, training and education has become a key area in hospitality. The Government of India has been taking initiatives to promote and develop hospitality and tourism both in terms of physical infrastructure and in terms of services by paying attention to uplifting physical products as well as manpower. National bodies like FHRAI (Federation of Hotel \& Restaurant Association of India) in association with HVS International conducted the Indian Hotel Industry Survey and a research on Status of Hospitality Education in India. Apex bodies like AICTE (All India Council for Technical Education) / UGC (University Grants Commission) have been funding seminars/ symposiums/ conferences in the field of Hospitality. Within the last five years various seminars like "Saga of Hospitality Education Quality Education" (2003), Practices in Travel \& Tourism Sector (2005), Seminar on Hospitality Education Issues \& Challenges (2005), Conference on Indian Hospitality Industry Contemporary Issues (2008) and other such conferences have been conducted from time to time so as to nurture the young talents as per the growing demands. Various researchers in India have conducted research on issues pertaining to hospitality education in India. Papers titled "Role of Hospitality Education in providing competent manpower", "Opportunities \& Dilemma's facing Graduate Hospitality Education in India.", "Tourism \& Hotel Management Education in India", "Hospitality Education in India - a case study" and other such related topics have been addressed in last five years. 
Most of the studies found that "Industry Institute Partnership" should be strengthened. The Hospitality Industry Associations can play a key role in Hospitality Education, research needs to be strengthened in Hospitality \& Tourism, Modular Programs can be offered, curriculum needs to be strengthened further, and skill upgradation programs need to be offered. Thus, the issues have been addressed in a significant way with a further scope for research. From the above mentioned one issue that comes is the common interface between Industry \& Institutes that is required. Perhaps the advisory committees / advisory boards of Universities can play a pivotal role here. Moreover, in an increasingly competitive job environment, hospitality educators must prepare students to know and meet the particular needs of their future employers. Considering the fact that the employers in hospitality are ultimately consumers of the skills and cognitive abilities that educators impart to students. Thus, industry cooperation is the need of the hour.

With the mounting competition in hospitality industry today, the market demands for higher levels of service, productivity \& value. The investment in people's training \& education becomes increasingly significant with the growing demands of the industry. Most of the hospitality employers express their differed opinion about graduates from vocational schools/ colleges \& university departments in India. Though the industry is not highly satisfied with vocational schools, it still is of the opinion that vocational schools serves the purpose better.

Thus, the study titled "Hospitality Education and Advisory Committees in Indian Universities: An analysis of academic success" has been a modest attempt to:

- Analyse hospitality education system in India;

- Ascertain the requirements of Indian Hospitality Employers;

- Understand and identify the gap between vocational schools, University Teaching Departments and Employers expectations and fulfilment;

- Suggest remedies to bridge this gap in terms of three stakeholders i.e. the students (Education Seekers) the Institutes/ Universities (Education Providers) and the Industry (Employers).

\section{Hospitality Education in India}

The origin of hospitality education in India is not very old. In the mid 1950's in Mumbai, the government introduced a hospitality course with United Nations Funding support. The Government of India initiated an education program in the field of hotel management catering technology \& applied nutrition in year 1962 
under the Department of Food, Ministry of Agriculture. To begin with, four Institutes of Hotel Management (IHM's) were set in New Delhi, Mumbai, Chennai and Kolkata for imparting training in hospitality related craft disciplines. Twelve Food Craft Institutes $(\mathrm{FCl})$ were also then set up at different places in the country. Consequent to the transfer of the program to the ministry of Tourism in October 1982, formats of various training programs were reoriented and remodeled keeping in view the performance workforce requirements in the country. In order to utilize the resources and to provide a central thrust to the program, Ministry of Tourism, Govt. of India also established The National Council of Hotel Management and Catering Technology in the year 1982. With the growth \& development of the hospitality industry in India, Hotel Management and Catering Technology Program has gained tremendous popularity and of course, the profile of students seeking admission to this course has undergone a tremendous change. So far, Three Year Diploma was the highest qualification offered by a Government Institute in India in the field of hotel Management.

Pleased with the fantastic placements and looking at the growing demands of Indian hospitality professionals overseas, the need of offering a degree program in Hotel Management was felt so as to give better opportunities to hospitality graduates globally. In the year 2003, The National Council of Hotel Management joined hands together with IGNOU (Indira Gandhi National Open University) and upgraded the three-year diploma program to a B.Sc Degree program in Hospitality \& Hotel Administration. In the year 2004, the stepping-stone to success of Indian Hospitality Education was added by the introduction of M.Sc program in Hospitality by National Council at four IHM's initially. As of 2008, there are $27 \mathrm{IHM}$ 's and a few more are expected (Table-1)

\begin{tabular}{|l|l|l|l|}
\hline IHM - Srinagar & IHM - Shimla & IHM - Chandigarh & DIHM - Chandigarh \\
\hline IHM - Gurdaspur & IHM - Pusa Delhi & IHM Laipat Nagar Delhi & IHM - Jaipur \\
\hline IHM - Jodhpur & IHM - Gwalior & IHM - Bhopal & IHM - Lucknow \\
\hline IHM - Gandhinagar & IHM - Mumbai & IHM - Thirvuanthpuram & IHM - Goa \\
\hline IHM - Dehradun & IHM - Bangalore & IHM - Hyderabad & IHM - Chennai \\
\hline IHM - Bhubaneswar & IHM - Kolkata & IHM - Shillong & IHM - Hajipur \\
\hline IHM - Guwahati & IHM - Gangtok & IHM Kurukshetra & \\
\hline Expected- & IHM - (Jharkhand) & IHM (Chhattisgarh) & \\
\hline
\end{tabular}

(Table-1) 
Other than IHMs, various Universities are imparting Hotel Management Graduate/ Post Graduate /Degree, PG Diploma's \& One Year Diplomas in India (Table -2)

University System in India: The Education Policy 1986 was the turning point in the Indian university system. We have different types of Universities such as with a single faculty, or multi-faculties; teaching or affiliating, or teaching cum affiliating, single campus or multiple campuses. Most of the Universities are affiliating universities, which prescribe to the affiliated colleges the course of study, hold examinations and award degrees, while undergraduate and to some extent post graduate colleges affiliated to them impart graduate instruction. Further as per National Policy on Education, 1986, a scheme of autonomous colleges was promoted. In the autonomous colleges, while the degree continues to be awarded by the University, the name of the college is also included. The colleges develop and propose new courses of study to the University for Approval. They are also fully responsible for the conduct of examinations. There are at present 138 autonomous colleges in the country. As on 31.3.2005, there were 342 Universities including 18 Central Universities, 211 State Universities, 95 deemed Universities and 5 institutions established under State Legislation and 13 Institutes of National Importance. There were 17625 colleges, of which 5386 have been recognized by the UGC under Section 2(f) and 12(B) of the UGC Act. In 2004-05, an estimated 104.81 lakh students were enrolled in the institutions of Higher Education as against 99.54 lakh in the previous year and the faculty strength was 4.71 lakh as compared to 4.57 lakh in the previous year.

Hospitality Education in Indian Universities: In terms of Hotel Management, about 18 Universities are offering the hospitality programmes in India in their University Teaching Departments/ Distance mode (Table-2) In the University system, hospitality education has ventured lately in India. It was in the year 1996, MJP Ruhelkhand University Bareilly launched 4 year Bachelor of Hotel Management \& Catering Technology programme in India. Subsequently Bundelkhand University, Jhansi (2001), BIT Mesra (2003), HNB Garhwal University, Srinagar Garhwal (2004), and other Universities launched hotel management programmes in their campuses. In terms of launching Masters Programmes in Hotel Management (MHM) they were launched in Kurukshetra University, Haryana (2002), Bundelkhand University, Jhansi \& MD University, Rohtak (2005).

\section{Hospitality Courses Available in India}

\footnotetext{
- 6-month Certificate Course in Hotel and Catering Management

- 1-year trade Diploma Courses in
} 
:- Bakery \& Confectionery

:- Hotel Reception and Book Keeping

:- Restaurant and Counter Service

- 3-year Diploma in Hotel Management

- 4-year Bachelor of Hotel Management \& Catering Technology

- 3-year B.Sc. in Hotel Management

- 3-year BBA in Hospitality \& Hotel Administration

- 3-year BA in Hospitality \& Tourism Management

- 1 -year PG Diploma in International Hotels

- 2-year M.Sc. in Hotel Management

- 2-year MHM - Masters in Hotel Management

- 2-year MBA - Hospitality/Hotel Management

- 2-yesr M.Sc. -Hotel Management

- 1 -year M Phil in Hotel Management

- Lateral entry programmes in both Undergraduate and Postgraduate level.

In table (2) the universities not offering a Hotel Management Program in their own campus have not been listed. However they offer it only through affiliated institutes/ colleges. For eg. Saurashtara University, Bangalore University, GGS Inderprastaha University, DAW Indore and other such universities offer hospitality programs only through affiliated institutes/ colleges. Thus, about 10,000-12,000 students pass out every year from hospitality programmes. Almost 5,000-6,000 students pass out from Diploma, craft course and short-term courses offered by associations (National \& International) like AHLA, State technical boards, Foreign Collaborations and others. Within the past five years, the number of pass out students has almost doubled, whereas Open \& Distance learning students have not been counted in the list of passing out students. The Government of India has formulated various norms and guidelines to keep a check on quality via its statutory bodies like AICTE, UGC and NBA. The Institutes offering Four Year Graduate Programmes are to seek approval from AICTE Open \& Distance Learning programs must be approved from DEC (Distance Education Council) in India, while the three year BBA/ BSc program in hotel management needs an approval and affiliation from a University. 
List of Universities imparting Hotel Management Graduate/ Post Graduate/ Degree, PG Diploma's \& One Year Diplomas in India in their campus/ University Teaching Department/ Distance Education (Table -2)

\begin{tabular}{|c|c|c|c|c|c|c|}
\hline Name of University & $\begin{array}{c}\text { Regular } \\
\circledR / \\
\text { Distance } \\
\text { (d) }\end{array}$ & PhD & $\begin{array}{l}\text { M.Sc. } \\
\text { MHM/ } \\
\text { MBA } \\
\text { (HM) }\end{array}$ & \begin{tabular}{|c|} 
B.Sc./ \\
BBA \\
(HM) \\
BHMCT
\end{tabular} & $\begin{array}{c}\text { PG } \\
\text { Diplo- } \\
\text { ma }\end{array}$ & \begin{tabular}{|c|} 
One \\
Year \\
Diplo- \\
ma
\end{tabular} \\
\hline Allahabad Agricultural Institute & (d) & - & - & Y & - & - \\
\hline Annamalai University - Tamil Nadu & (d) & - & Y & Y & Y & Y \\
\hline Barkatullah University - Bhopal & (d) & - & - & - & Y & - \\
\hline Bharati Vidya Peeth University - Pune & 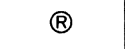 & - & - & $Y(O) /(A)$ & - & - \\
\hline Birla Institute of Technology - Ranchi & (®) & - & $Y^{\wedge}$ & $Y(O)^{\wedge}$ & $Y \wedge$ & $Y^{\wedge}$ \\
\hline Bundelkhand University - Jhansi & $®$ & $Y$ & $Y(0)$ & $Y(0)$ & - & - \\
\hline Christ University, Bangalore & $\mathrm{R}$ & - & - & Y & - & - \\
\hline $\begin{array}{l}\text { H.N.B Garhwal University - } \\
\text { Srinagar Garhwal }\end{array}$ & ® & Y & - & $\mathrm{Y}(0) /(\mathrm{A})$ & Y & - \\
\hline $\begin{array}{l}\text { Indira Gandhi National Open } \\
\text { University }\end{array}$ & (d) & - & $Y(s)$ & $Y(s)$ & - & - \\
\hline Kurukshetra University - Haryana & $\circledast /(d)$ & Y & $\begin{array}{c}Y \AA \\
(o) /(d) \\
\end{array}$ & $Y(A)$, (ic) & $Y(d)$ & - \\
\hline M.D University - Rohtak Haryana & $\circledR$ & - & $Y(0)$ & $Y(A)$ & - & - \\
\hline M.M University Mullana & 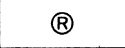 & - & $Y(0)$ & $Y(0)$ & - & - \\
\hline M.P Bhoi Open University - Bhopal & (d) & - & - & - & Y & - \\
\hline MJP Rohilkhand University - Bareilly & ( & Y & - & $Y(0)$ & - & - \\
\hline Punjab Technical University & (d) & - & Y & Y & - & - \\
\hline $\begin{array}{l}\text { Uttarakhand Open University - } \\
\text { Haldwani }\end{array}$ & (d) & - & - & Y & - & Y \\
\hline $\begin{array}{l}\text { Vardhman Mahaveer Open } \\
\text { University - Kota }\end{array}$ & (d) & - & - & - & - & Y \\
\hline $\begin{array}{l}\text { Vinayaka Missions University - } \\
\text { Tamil Nadu }\end{array}$ & (d) & - & Y & Y & - & - \\
\hline $\begin{array}{l}\text { Yashwant Rao Chauhan Open } \\
\text { University - Maharashtra }\end{array}$ & (d) & - & - & $Y(i c)$ & - & - \\
\hline
\end{tabular}


(o) - On Campus; (a) - Affiliated Institute; ${ }^{\wedge}$ - International Centre, (ic) Industry Collaborative Program; $(\mathrm{s})$ - Specific designed program in collaboration with NCHMCT.

\section{Advisory Committees \& Universities in India}

Generally, a board of studies, advisory boards \& other such committees govern the academic activities of almost all Universities in India. The advisory board meetings are conducted from time to time by most of the Universities varying between the time schedule of one to three years. The minutes of advisory board meeting of universities offering hotel management programmes in their campuses have been reviewed on convenient sampling basis so as to ascertain the requirements of Indian Hospitality Employers. An advisory committee formally consists of academicians, renowned industry people and other experts. The main purpose of the hospitality management council is to enhance collaboration between the hospitality educational institutions and the business committee. Further, the council will provide advice, insight and vision to the faculty and students of hospitality management especially for strategic planning and curriculum development. At the national level, Apex bodies like AICTE do maintain an advisory committee, an All India board of Hotel Management \& Catering Technology w.e.f. 01 Sept 2006 has been constituted and a model curriculum has also been proposed along with guidelines for Hotel Management Institutes. A majority of the advisory meetings have emphasised on synergy between industry \& academia. The discussions have focused on: updating academic developments of University, Training \& Placement issues, Research \& Publications; Conferences \& Seminars and other such related matters.

\section{Identification of Gap}

Practically, the Industry expects more polished candidates with an emphasis on application and skill utilization whereas universities focus on research and holistic development. The industry expects niche specialization while the universities focus on content and more theoretical knowledge as the base. The industry emphasises on guarding the prospective candidates against dilemmas of higher expectations whereas universities focus on multi availability of opportunities. The industry proposes to make learners more familiar and participatory in events, fairs \& exhibitions whereas academic fraternity shows time limitation, as the curriculum needs to be covered in the stipulated time frame. Furthermore, the Industry focuses on mentoring introduction and strengthening whilst academic community has its own limitations. Internships / training are more emphasised by the industry where as academic 
community believes that the internship needs to be more organised and not mere utility of manpower. On the other side of the coin i.e. Academic institutions expect more systematic participation of industry in terms of research projects where as industry cites time as a major constraint. Academic institutions look forward to more concept clarity and formal training while the industry has to keep the emphasis on business as first priority. Thus, there are several such issues from both ends. Overall vocational Institutes are able to fulfill the skilled manpower requirement and the universities in varied ends like research, operations and management. The single focused approach has been a practice and attained acceptance whereas multi focused approach may still take time to be accepted. These facts are supported by previous studies such as Tas (1998) who asserts that graduates should have multi-skills base, which allows them to be creative, flexible \& adaptive. Gamble and Messenger, 1990 cites due to diverse nature of hospitality industry, it is not easy to precisely define the skills and competencies of a hospitality management graduate. Researchers such as Hersey \& Blanchard (1998) as well as Van Dyke and Strick (1990) include technical, human, conceptual, \& demonstration of organisation skills, people skills \& leadership as important competencies. Baum \& Nickson (1998:79) argue "that hospitality students require a real in-depth understanding of the industry and HRM issues within it from a theoretical and conceptual point of view before they are given operational and prospective models on how to operate within that environment." Cooper \& Westlake, (1998) suggests that academics, students \& curricula, develop and benefit from close links with the industry. According to Rigel (1996), substantive knowledge is the essential knowledge necessary for practice in the tourism profession. It is the core area upon which instruction is based. The skill component, which consists of abilities, is necessary and it is to apply professional knowledge in the field of work. The value component which it involves, foster key career values, necessary for success in that field. Busby (2005) cites that tourism linkages \& strategies in many educational institutes are often haphazard and lack vision, focus, commitment \& resources (Cooper \& Westlake 1998.) Busby (2005) further points out that industry linkages strategies do exist; they are often centered on industrial placement models. In this part, it represents the old way of thinking about industry engagement - with quantitative hours but with no qualitative considerations of the standard of experience in the industry.

The Possible Gap Model: the studies reveal that there is huge gap, which can fundamentally be expressed in terms of a model. The model identifies the possible areas of gap in liasoning mentioned in the model below (Figure 1). 


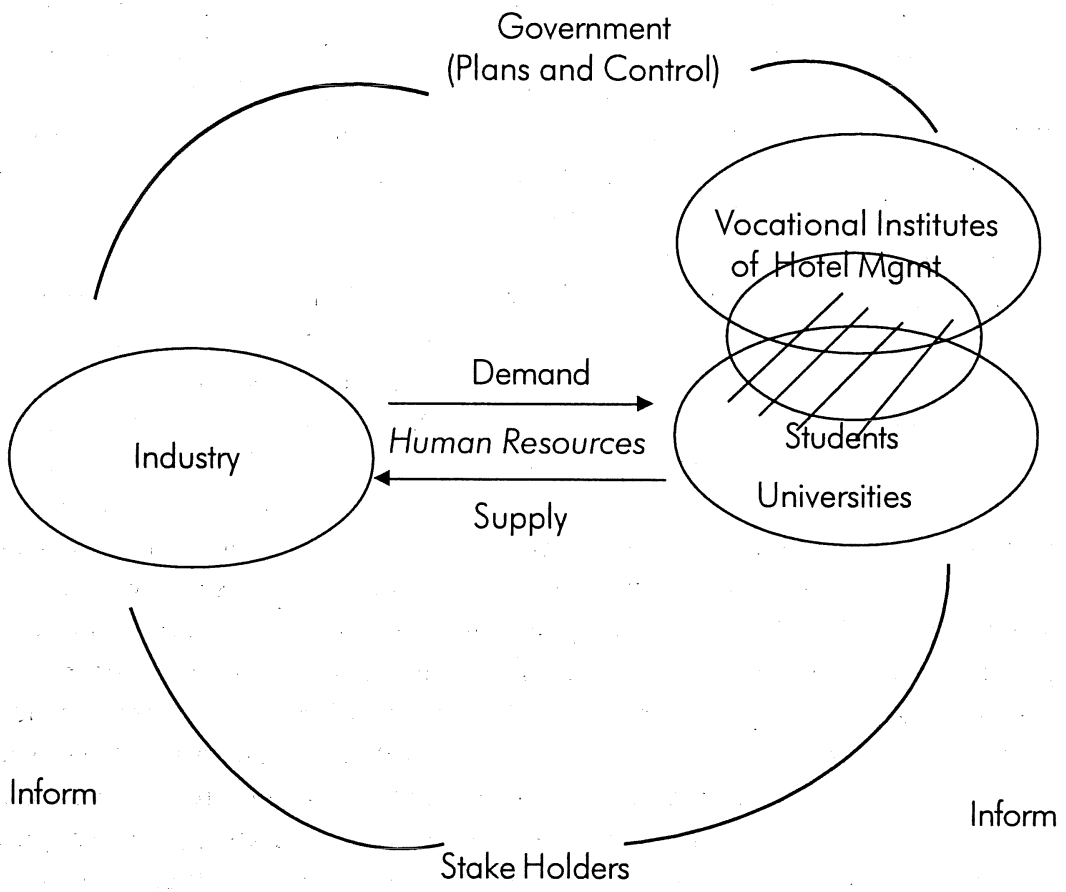

Figure: 1

Figure 2 further explores the gap between the hospitality educational institutions and industry. It is clear that in today's volatile hospitality marketplace, it has become imperative for both hospitality educational institutions and industry to enter into a strategic alliance i.e. hospitality education and industry interface. A collaboration model seeks to develop an environment in which student-centred and experienced learning is valued and in which students, faculty members, and industry professionals jointly engage in the hospitality course design and development of industry-oriented education. It is observed that linking hospitality management programmes to industry is critical for the success of hospitality educational institutions. Further, representatives who have gained experience in various hospitality areas bring a much richer perspective to discussions catering to the needs of the industry and life skills for hospitality students. 


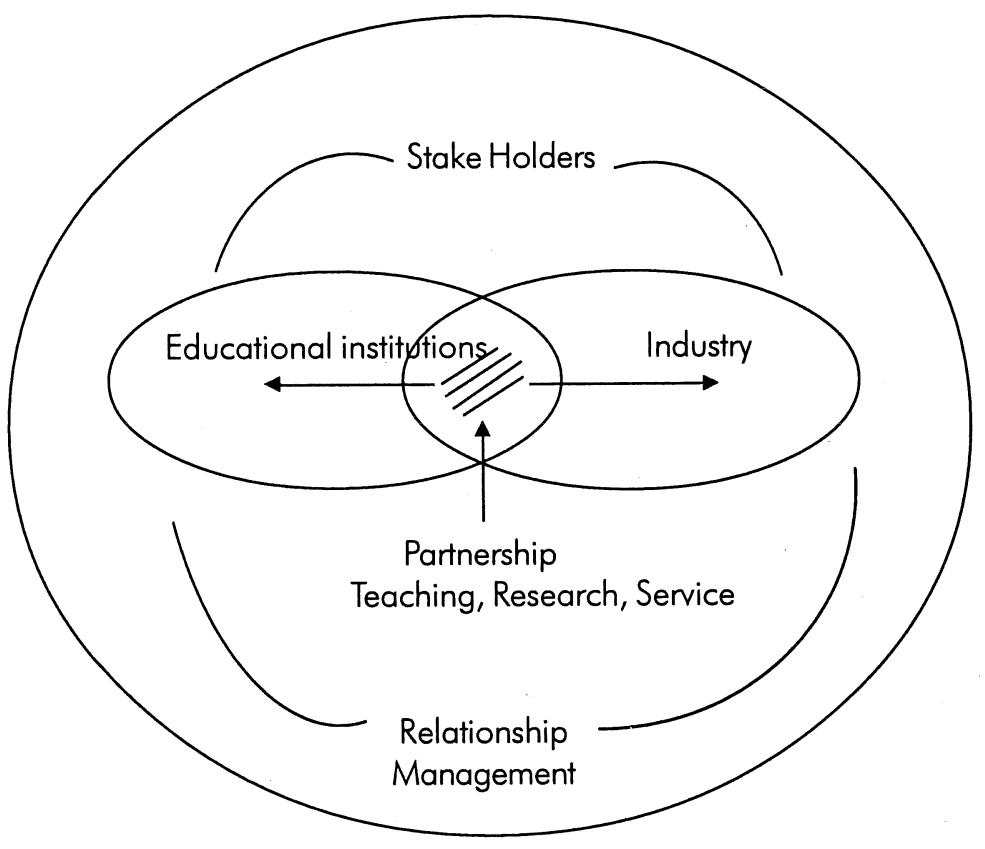

Figure: 2

\section{Recommendations \& Suggestions}

The article aims to analyse hospitality education system in India and to ascertain the requirements of the Indian Hospitality Employer. There is possibly a gap between vocational schools, University Teaching Departments and Employers expectations and fulfilment. Advisory committees can bridge this gap. In the possible gap model, we could trace the gap between three significant Stakeholders i.e. the students (Education Seekers), the Institutes/Universities (Education Providers) and the Industry (Employers). The relationship clearly exists between students (Education Seekers), the Institutes/ Universities (Education Providers) and the Industry (Employers). Jain et al (2003) have suggested that applying a relationship management approach can be successfully applied to gain understanding about ways in which relationships can be enhanced. The advisory committees can play a pivotal role here (Figure3). Further, advisory committees can develop a relationship between education \& industry and create a synergy at the top level. 


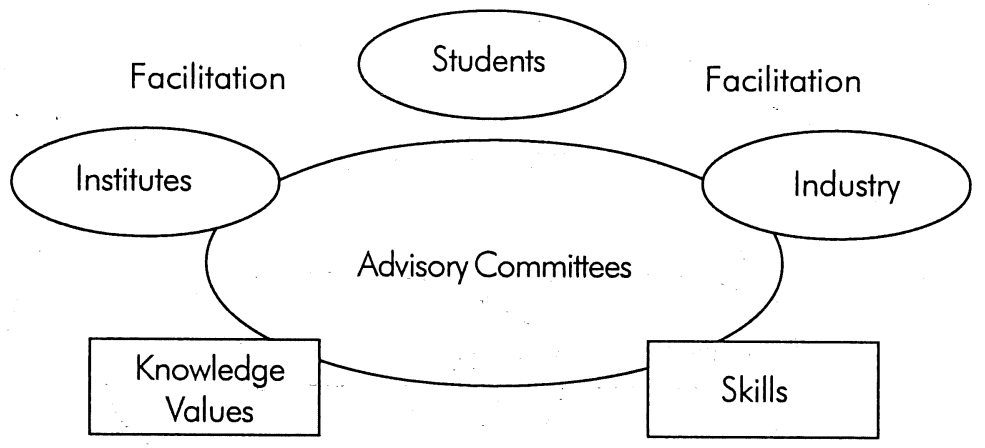

Figure: 3

A key priority in this regard will be to balance the industry demand and institute supply of trained manpower. Efforts need to be made to ensure that the existing hotel management issues of Universities are evaluated on an annual basis in accordance with trends in the changing environment and industry needs and priorities. In this regard, a close contact is to be maintained with key hotel organizations and industry opinion leaders and experts. However advisory committees have already taken steps and have suggested remarkably well the development of human resources to meet the international standard of the hospitality industry. But they have to be traveled by the good balance of knowledge and values too (Dahiya2007).

Advisony committees should play a more active role in educating government decision makers about the critical contribution of education and try developing successful hospitality and tourism manpower for the industry. They can take steps to increase awareness about vocational education and the university system to the hospitality and tourism sector. Review and recommendations can be made concerning policies, programs, and initiatives designed to support and promote the hospitality programmes as well as for intellectual and professional development of the university's work force. Initative needs to be taken so as to strengthen the publications particularly in the Indian context. Textbooks authored by Indian authors on Indian hospitality are very limited. Thus, Advisory committees can encourage young authors, senior academia as well industry professionals to contribute. Research is a key area of attention in the Indian hospitality sector. In the present system, majority of Universities have collaborated or seek support from external research agencies. Advisory committees can persuade/ propose research grants projects to be submitted to the Government for sanctioning of research grants. In order to strengthen education at the roots, scholarships should be promoted. Advisory committees 
should encourage industry to assist in scholarships for hospitality students further, so they can play a key role by facilitating placement fairs annually in liasoning with the industry \& directing Institutes so as to help students in placements.

\section{References}

- Bagri SC (2007) - Hospitality Education in India- Case Study, JOHAR-Vol-1 No.1 page-1-14

- Barron PE (1996) - The theory \& practice of Industrial placement : an analysis of hospitality students experiences, Australian Journal of Hospitality Management, Vol -4(1), 15-26.

- Busby G (2005) - Work Experience \& Industrial Links, In D Airey and J Tribe (Eds), An International Hand book of Tourism education London : Elsevirer.

- Bawm, T (2002) - Skills and Trip for the Hospitality Sector: a review of issues. Journal of Vocational Education and Training Vol.54 no.-3 page-243-263.

- Chand Mohinder (2006) - Tourism Education in India and HR Practice in Indian Tourism Industry- Tourism in India Policy Issues and Implication page-104-131.

- Clayton,W. Barrow and Robert H.Bosselman, (1999) Hospitality Management Education, The Haworth Hospitality Press, New York.

- Cooper C \& Westlake J (1998) - Stakeholders \& tourism education - Curriculum Planning using a quality management framework, Industry \& Higher Education, 12(2), 19-100.

- David, Richard \& Cooper - An Industry Parternership approach to Tourism education, Journal of Hospitality, Leisure, Sport \& Tourism Education, Vol 6 No-1 P66-70.

- Dahiya Ashish (2007) - Developing Human Resources in Travel and Tourism Industry. CMTHS publication page-86-93.

- Dahiya Ashish (2006) - Opportunities \& Dilemmas facing graduate education in Hospitality \& Tourism in India. Cutting Edge Research in Tourism, Abhishek Publications Pages-584595.

- FHRAI News (2005), vol. xxx, no.-3, New Delhi.

- Jain, Jain \& Khar (2003) Measuring Customer relationship management, journal of Services Resaerch 2(2), 97-108.

- Higher Education in India - Annual Report 2006-07.

- King BE (1991) Cooperative Education for Hospitality \& Tourism students: An Australian case study, New Horizons in Tourism \& Hospitality Education Training \& research, Calgray 19-126.

- Lewis, RC.C (1993) - Hospitality management education here today gone tomorrow? Hospitality Research Journal vol.17 page-273-283.

- Lu James (2004) - The role of Advisory Committees in Universities, Journal of Teaching in Travel \& tourism Vol-4 No-4 P 47-54.

- Market Pulse Report (2004) - Ministry Of Tourism, Government of India. 
- Marktola Kamal (2007) - Role of hospitality education in providing competent manpower, HR Practices in travel and tourism industry page-11-30.

- The Cornell Hotel and Restaurant Administration Quarterly Vol: 34, no. 4, pages-83-89.

- World Travel and Tourism Council (1994) - Gearing up for growth: a study of Education and Theory for career in Asia Pacific travel and tourism sector, Brussels, Belgium.

- Zafari, Zafar (1990), Research and Scholarship basis of Tourism Education, The Journal of tourism studies vol.1, no.1. 